\title{
ДИСКУССИИ
}

\section{Выступление Лорда-Мэра Лондона Ольдермана Яна Людера на круглом столе «Государственно-частное партнерство». Тезисы статей}

\author{
Кокорев Д.А. ${ }^{58}$
}

Данная статья является переводом выступления Лорда-Мэра Лондона Ольдермана Яна Людера на круглом столе «Государственно-частное партнерство - механизм преодоления кризисных явлений и структурных проблем экономики» организованным ГУВШЭ и британской фирмой «Grant Thornton».

$J E L: G 24 ; G 28$

Ключевые слова: государственно-частное партнерство, инвестиции

Дамы и Господа,

Как Лорд-Мэр Лондона, я вижу значимость государственно-частного партнерства (ГЧП), активно практикующегося в Великобритании и по всему миру, поэтому я хотел бы кратко рассказать о богатом опыте Великобритании в ГЧП и его применении в текущих условиях.

Кризис существенно отразился на:

1) Доступности и затратах на финансовые ресурсы, необходимые для проектов

2) На экономическом благополучии российских и международных компаний, принимающих участие или только победивших в конкурсах на участие в проектах ГЧП

3) Доступность муниципального и федерального софинансирования

4) (прежде всего) соотношение риска и доходности, что приводит к меньшей привлекательности некоторых проектов для частного сектора

Если в данной ситуации и есть положительные новости, так это тот факт, что в Великобритании большинство хороших проектов продолжают реализовываться. Учитывая существенные вложения в инфраструктурные проекты в Великобритании при использовании инструментов ГЧП, нам также приходилось сталкиваться проблемами, которые сейчас актуальны в России.

Для понимания объемов ГЧП и наших обязательств, приведу несколько цифр: на текущий момент одобрено 935 проектов ГЧП с общим объемом финансирования в 66 миллиардов фунтов стерлингов, что составляет порядка $10-15 \%$ инвестиций частного сектора с 1996 года. Несмотря на падение количества ГЧП проектов до уровня, ниже среднегодового значения 60 в период 2005-2007 гг. до 34 в 2008 году, общая стоимость проектов 2008 года сократилась только на 11\% по сравнению с 2007, составив 6,5 миллиардов фунтов стерлингов. Средняя величина проекта в прошлом году составила 192 миллиона фунтов стерлингов, при этом стоимость одной сделки достигла 2,5 миллиардов фунтов стерлингов. Все эти цифры говорят о том, что при правильном структурировании проектов, даже в кризис она продолжают осуществляться.

\footnotetext{
${ }^{58}$ Аспирант факультета экономики, кафедра экономики и финансов фирмы ГУ ВШЭ. 
И, так как Лондонский Сити активно участвует не только в ГЧП проектах на территории Великобритании, но и в Испании и Южной Африке, мы можем оценить воздействия кризиса и на другие страны.

Итак, что же должно быть ответом на текущие проблемы? Я уверен, что нельзя использовать универсальный подход. Проблемы, связанные с ГЧП проектами, требуют различных типов решений, которые в свою очередь зависят от большого количества факторов мировой и локальной экономик, гибкости центральной и местной администрации, масштаба и длительности каждого проекта, механизма реализации проекта. Но ключевым вопросом, все же, является соотношение «риск/доходность», и те меры государственного вмешательства, которые могут и должны быть предприняты для регулирования данных параметров.

Несколько мыслей в данном направлении:

1) Существует множество различных возможностей. Например, продление концессионного соглашения, субсидии, гарантия доходов проекта, гарантии по кредитам, займы, свопы, различные меры вмешательства. Выбор правильной комбинации всех этих мер, позволяющей нивелировать риски проектов, является сложной задачей.

2) Государство должно быть аккуратным при взятии на себя новых рисков. Вливания должны быть правильно финансово обоснованы, иметь экономический и фискальный смысл, а также должны публично освещаться и обсуждаться.

3) Если мы верим в то, что кризис представляет собой временное явление, то неизменные условия соглашений не являются обязательной догмой. Как только один из внешних факторов изменяется (например, затраты на заемное финансирование), корректное использование изменения некоторых параметров контракта может способствовать возвращению к прежним уровням риска и доходностей проектов ГЧП.

4) Для того чтобы сделать все вышеперечисленное корректно, государству необходимы советы экспертов в данной области. Сейчас не время для того, чтобы делать судорожные изменения работающего механизма, без правильной оценки технических, юридических и финансовых последствий.

Я не удивлю Вас, сказав, что наиболее полную и объективную информацию при поиске ответов на обозначенные выше вопросы вы сможете найти в Лондонском Сити.

Спасибо. 